universities, medical schools and Government. At the present time in the United States some hundred students are training at postgraduate-level in seven centres offering biomedical engineering facilities. There is no doubt that this type of training will expand and extend. At Glasgow, postgraduate research facilities exist in this field at the Royal College of Science and Technology, and at present three full-time researchstudents work on bio-engineering projects.
The future in research, one would surmise, lies with collaborative medical engineering teams rather than with biologically trained engineers. Yet it is essential to keep an open mind on these matters, and there is one thing certain - there is no shortage of problems or of opportunities to participate in a deeply interesting activity with an enormous potential of contributions of basic value to come.

\title{
THE ALASKA EARTHQUAKE OF MARCH 28-30, 1964
} UST after 5.36 p.m. on Friday, local time, when many
of the people of Anchorage, Alaska, were homeward
bound, thinking no doubt of getting indoors again out
of the snow and freezing temperatures, suddenly and
without warning the first seismic shock occurred. Imme-
diately, buildings in the city centre collapsed, ground
fissures appeared, down which cars slumped (one fissure
was almost $100 \mathrm{ft}$. long with a drop of $10 \mathrm{ft}$.), and the
control tower at the airport came toppling down. Imme-
diately also, more than 1,000 houses were destroyed, water
pipes, electric power lines and gas mains were severed,
and communications disrupted. Many people were killed
and injured. When the impact of the first shock was past,
the city's services with all possible assistance drove into
action. Residents were asked not to use the sewers,
people queued for typhoid inoculations and hospital
services were overworked. The State of Alaska was a
disaster area. On the Gulf of Alaska, the village of
Valdez was evacuated, apart from the necessary officials,
owing to lack of water, sanitation and other services, and
an emergency evacuation camp was set up at Gulkana,
about 110 miles away. Seward, also on the Gulf of Alaska,
was half destroyed and there were numerous fires since
the earthquake had scattered the house fires as it passed.
The village of Tuguyak on Kodiak Island was almost
completely destroyed. The ripples from this earthquake
focus sped through the solid earth to be recorded at
seismological observatories throughout the world. The
tsunami warning system began its calculations.

At the moment of disaster the tsunami or seismic sea wave set out from near the epicentre and, shortly after, the tsunami warning system went into action and messages were flashed to all parts of the Pacific. The sea waves were about $30 \mathrm{ft}$. high at Kodiak and Cordova in Alaska, and $8 \mathrm{ft}$. high when they arrived at Oahu, Hawaii. At Vancouver Island the sea-level rose as the waves passed, and at Crescent City in northern California five oil tanks were destroyed by the 12 -ft.-high waves. The waves eaused a break in the Commonwealth telephone cable connecting Canada with Australia and New Zealand, at a point about $7 \frac{1}{2}$ miles off the Canadian Pacific coast near Port Alberni in British Columbia. The waves were significant on tide gauges in Japan.

Preliminary determinations of the epicentre of the shock place this at $61 \cdot 1^{\circ} \mathrm{N} ., 147 \cdot 8^{\circ} \mathrm{W}$. The depth of focus is considered shallow, and the Richter logarithmic magnitude between $8 \cdot 2$ and $8 \cdot 6$, making this one of the world's greatest earthquakes. The epicentre is east of Anchorage, Alaska, and the origin time was 1964 March $28 \mathrm{~d} 03 \mathrm{~h} 36 \mathrm{~m} \mathrm{10s}$ G.м.т. The complete death-roll and damage are not yet known. In Alaska, 65 are known dead as the result of the earthquake, and damage is estimated at more than 250 million dollars. In Crescent City, California, due to the tsunami, 12 people are known dead and there was major damage to property. Aftershocks are still continuing. Eight above magnitude 6 were experienced on the first day, March 28, and there were many smaller ones. On March 30 , at $02 \mathrm{~h} 18 \mathrm{~m}$ 05s G.M.T. from the Kodiak Island region, came a shock of magnitude $6 \cdot 7$.
The Aleutian Islands arc from Komandorski Islands to Alaska, and Alaska itself must be considered a major seismic and volcanic zone of the Earth. For example, in the year 1959 there were some 40 earthquakes felt and recorded in Alaska. Shocks greater than magnitude 6 and of shallow depth of focus near to the present epicentre also occurred at the following times and places: 1932 September $14 \mathrm{~d} 08 \mathrm{~h} 43 \mathrm{~m} 23 \mathrm{~s}$ G.M.T., $61^{\circ}$ N., $148^{\circ}$ W. $\left(6 \frac{1}{4}\right)$; 1933 January $04 \mathrm{~d} 03 \mathrm{~h} 59 \mathrm{~m} 28 \mathrm{~s}$ G.M.T., $61^{\circ} \mathrm{N} ., 148^{\circ} \mathrm{W}$.

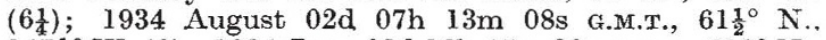
$1471^{\circ}$ W. (6); 1934 June $02 \mathrm{~d} 16 \mathrm{~h} 45 \mathrm{~m} 29$ s G.M.T., $61^{\circ}{ }^{\circ}$ N., $147^{\circ} \mathrm{W} .\left(6 \frac{1}{4}\right)$ : and earthquakes with intermediate depth of focus (about $80 \mathrm{~km}$ ) occurred at: 1912 January $31 \mathrm{~d}$ $20 \mathrm{~h} 1 \mathrm{~lm} 08$ s G.M.T., $61^{\circ}$ N., $147 \frac{1}{2}^{\circ}$ W. $\left(7 \frac{1}{4}\right) ; 1934$ May 04d $04 \mathrm{~h} 36 \mathrm{~m} \mathrm{07s} \mathrm{G.M.T.,} 611^{\circ} \mathrm{N} ., 147 \frac{1}{2}^{\circ}$ W. $(7 \cdot 2)$.

Perhaps the greatest of the previous Alaskan earthquakes were on September 3 and 10, 1899, at Yakutat Bay, the latter being the greater, though from seismograms both had magnitude between $8 \frac{1}{4}$ and $8 \frac{1}{2}$. The area was visited shortly before the earthquake by the Harriman glacier exploration expedition, who took photographs, and about 6 years after the earthquake by a party of the U.S. Geological Survey. The shocks were accompanied by block faulting, and the largest known displacement by a single group of earthquakes then occurred. At maximum there was a permanent uplift of $47.5 \mathrm{ft}$.

At the time of the shock a small party of prospectors was camped near by on a glacier. Above them an ice dam holding a glacier lake broke, landslides happened all around, and a great wave $30 \mathrm{ft}$. high in the bay swept away their boat. Fortunately, they recovered the boat and escaped by sea, since the adjacent land was so cut up as to be almost impassable. The region was otherwise uninhabited. Outside the bay the sea wave was extremely small. Large seismic sea waves, or tsunamis, have been sent right across the Pacific Ocean from earthquake epicentres at various times, for example, from the Arica earthquake of 1868 and from the Iquique earthquake of 1877. A great wave destructive at Hilo came from the small Aleutian Islands shock of April J, 1946, although a very small wave had resulted from the strong earthquake in the same Aleutian Islands region of November 10, 1938. Large tsunamis came from the earthquakes in Chile in May 1960 and from the present Alaskan shock.

In the Aleutian Islands are shallow-focus seismicity follows the northern concave side of the Aleutian trench, being less intense near the Komandorski Islands. At the eastern end of the arc activity is higher near the Kenai Peninsula. This seismic activity is only exceeded by that of Mexico, Japan and the Solomon Islands. Shallow-focus earthquakes with depths from 50 to $70 \mathrm{~km}$ are frequent, and intermediate-focus earthquakes with depths from 100 to $170 \mathrm{~km}$ occur along the northern side of the Aleutian Islands arc and on the Alaska Peninsula from $176^{\circ}$ to $160^{\circ} \mathrm{W}$. The shallow shocks in the interior of Alaska indicate an interior structure related to the Pacific coastal arc, in the same way as the Rocky Mountains are related to the Pacific coastal ranges farther south in America.

ERnest TILIOTSON 